\title{
Corporate Governance in China: A Research Agenda for a Corporate Group and Shareholder Control Perspective
}

\author{
Jenny Fu \\ Victoria University, Australia
}

\begin{abstract}
The share ownership structure of listed companies in China lends support to the research findings of the recent "concentrated share ownership" thesis. However, due to its particular economic, political and legal contexts, the Chinese share ownership structure has its own characteristics. Instead of rich families or banks as seen elsewhere, publicly traded corporations in China are typically controlled by their stateowned founder/sponsor enterprises. Based on an examination of the state of ownership and control in listed companies in China and a brief review of the relevant literature, this paper suggests a corporate group contextual-based approach to understand corporate governance in China. For that purpose, some major issues for future research are also outlined.
\end{abstract}

\section{Introduction}

In their 1932 study of the top 200 largest American corporations, Berle and Means conceptualised the "modern corporation" as having dispersed ownership and the resulting shift in power from owners/shareholders to corporate managers. Developed from this notion, corporate governance in the Anglo-American system (of which Australia is a subset) has been about how best to solve the "agency problem" that occurs between diffused shareholders and managers in whose hands corporate control is concentrated ${ }^{1}$.

The Berle and Means image of the "modern corporation" however has been challenged by a number of recent studies which suggest that most firms are controlled by a single large shareholder outside the US and the UK. For example, according to Gorton and Schmid (1996), about 80\% of the large companies in Germany have an over $25 \%$ non-bank

Copyright (C) 2006 Victoria University. This document has been published as part of the Journal of Business Systems, Governance and Ethics in both online and print formats. Educational and non-profit institutions are granted a nonexclusive licence to utilise this document in whole or in part for personal or classroom use without fee, provided that correct attribution and citation are made and this copyright statement is reproduced. Any other usage is prohibited without the express permission of the large shareholder. La Porta et al.(1999) studied the ownership structures of the top 20 largest corporations in 27 of the wealthiest countries. Using a $20 \%$ definition of control, they found that almost half of those companies are ultimately controlled by families or the state through pyramid schemes $^{2}$. Further, adopting La Porta et al's methodology, Claessens et al.(2000) found

1 The agency problem was developed by Coase (1937), Jensen and Meckling (1976) and Fama and Jensen (1983). According to these authors, the agency problem is created by the separation of corporate ownership and control.

La Porta's definition of corporate pyramids is: (1) it has an ultimate owner, and (2) there is at least one publicly traded company between it and the ultimate owner in the chain of 20 percent voting rights. 
large family control in more than two thirds of East Asian corporations and that separation of ownership and control in this region is rather rare.

Whilst these research findings have generated doubts about the likely convergence of the rival systems of corporate governance around the world, considerable attention has been drawn to the role of large shareholders in aligning the interests of managers with those of the shareholders. Research in this area so far has produced varied interpretations. In the meanwhile, commentators have warned that the potential expropriation of minorities by large, controlling shareholders may create a new principle-agent problem that occurs between the majority and the minority shareholders (Claessen 2002).

The share ownership structure of listed companies in China lends support to the research findings of the recent "concentrated share ownership" thesis. As in many Western European and East Asian countries, high level share ownership concentration exists in the around 1400 Chinese publicly traded firms. However, in contrast to East Asian countries where publicly companies are often controlled by private investors through the use of corporate pyramids, the great majority of listed companies in China are directly controlled by closely held state-owned enterprises (SOEs). This unique feature of share ownership provides us with the opportunity to look at the complex agency problem in a context that has been far less dealt with in Anglo-America literature.

With the rise of China in the world economy, the corporate governance of Chinese listed companies has generated considerable research interest. However, most studies in this area so far have focused on a firm level analysis. Based on an examination of the state of ownership and control in the Chinese listed companies and a brief review of the relevant literature, this paper suggests a corporate group (ie., parent-subsidiary control) based approach to understand the mechanisms and practices of corporate governance in China. It is hoped that this would not only assist China's search for an effective structure of corporate governance, but also contribute to the ongoing international debate on the relative effectiveness of rival systems of governance. For that purposes, some major issues for future research will be outlined.

\section{Ownership and Control in the Listed Companies in China}

As a matter of socialist ideology and economic practicability, China strictly followed a centrally planned economy upon the founding of the PRC in 1949. By 1954 almost all the country's enterprises had become wholly state-owned, with their sole function dedicated to implementing state plans and their need for funds met by budgetary grants ${ }^{3}$. This state-owed and state-run system however left SOEs with little vitality. Towards the late 1970s, the whole Chinese economy was on the verge of bankruptcy, which served as the propelling force behind China's embarking on a course of market-oriented economic reform.

The initial reform only sought to improve efficiency of SOEs through granting limited autonomy and incentives to the SOE managers without disturbing the state ownership. It was not until 1987 when establishing a shareholding system was for the first time endorsed by the Communist Party. By then it had adopted a more pragmatic view that the shareholding system was not incompatible with the ideals of socialism and public ownership ${ }^{4}$. Further, based on shareholding experiments over the ensuring years, the Party in 1993 formally committed itself to the establishment of a "modern enterprises system". The nationwide corporatisation of SOEs was thus initiated. To facilitate the corporatisation reform, China's two stock markets, namely the Shanghai Stock Exchange and the Shenzhen Stock Exchange, were established in 1990 and 1991 respectively. In a similar vein, the first PRC Company Law was introduced in 1993 and the Securities Law in 1998.

3 In 1978, China had 83,000 SOEs and a large number of urban and rural collectives. The output value of the state-owned industrial enterprises accounted for $80.80 \%$ of the total industrial output in China. See Yifu Lin, Sufficiency of Information and State-owned Enterprise Reform, Shanghai Sanlian Book Store and Shanghai People's Press, 1997.

4 See "Advance along the Path of socialism with Chinese characteristics," [Yanzhe You Zhongguo Tese De Shehui Zhuyi Daolu Qianjin] (in Chinese), Report of the Thirteenth Party Congress in October 1987. 
In a short fifteen years, China has made remarkable achievements in building two stock markets consisting of around 1400 listed companies, with a total market capitalisation close to half of the country's GDP ${ }^{5}$. In terms of corporate governance structures, the current arrangements in Chinese listed companies represent a mixture of those in the mature economies. Inspired by the German-Japanese experiences, the 1993 Company Law adopted three governance structures: (1) the shareholders' general meeting (2) the board of directors and (3) the board of supervisors which, far less powerful than its German counterpart, is only charged with the role to monitor the directors' board. Further, under the recent influence of the Anglo-American systems, Chinese listed companies have also been mandated by the CSRC (China Securities Regulatory Commission) to set up board committees and have at least onethird independent directors sitting on the board. It seems that as a result of shopping around the world for best governance structures, the current corporate governance arrangements in listed companies in China are not markedly different from those in the Western economies. However, due to the original design and special purpose of the Chinese stock markets, the underlying ownership and control in listed companies in China is particularly unique.

Since 2002, listed companies have been required by CSRC to disclose their ultimate controlling shareholders. Thus, among the 1175 companies listed in 2002, 1051 were announced having controlling shareholders. The dominant position of the largest shareholders can be further illustrated in the table below:

Table 1: Percentages of Shareholdings for Top 10 Shareholders in 'A' Share Listed Companies in China (1998-2002)

\begin{tabular}{|l|l|l|l|l|l|l|l|l|l|l|l|}
\hline Year & No.1 & No.2 & No.3 & No.4 & No.5 & No.6 & No.7 & No.8 & Nio.9 & No.10 & Total \\
\hline 1998 & 46.22 & 7.63 & 3.16 & 1.83 & 1.20 & 0.87 & 0.65 & 0.53 & 0.43 & 0.38 & 62.89 \\
\hline 1999 & 45.63 & 8.10 & 3.27 & 1.84 & 1.22 & 0.88 & 0.68 & 0.55 & 0.46 & 0.40 & 63.02 \\
\hline 2000 & 45.28 & 8.26 & 3.24 & 1.78 & 1.16 & 0.80 & 0.61 & 0.48 & 0.40 & 0.34 & 62.35 \\
\hline 2001 & 44.37 & 8.36 & 3.27 & 1.76 & 1.11 & 0.75 & 0.56 & 0.43 & 0.36 & 0.31 & 61.28 \\
\hline 2002 & 45.92 & 8.61 & 3.24 & 1.76 & 1.13 & 0.78 & 0.59 & 0.45 & 0.37 & 0.31 & 63.17 \\
\hline Average & 45.30 & 8.33 & 3.26 & 1.79 & 1.16 & 0.80 & 0.61 & 0.48 & 0.40 & 0.34 & 62.46 \\
\hline
\end{tabular}

Source: Shenzhen Securities Information Database cited in Gao (2004)

On average, the largest shareholders owned more than $45 \%$ of company shares, about three times the total shareholding of the second to tenth largest holders. According to the Shanghai Stock Exchange (2003), generally, the larger the size of a company, the higher the percentage of shares held by the controlling shareholder.

Further statistics from the former State Trade and Economic Commission revealed that instead of individuals or government agencies, $71 \%$ of the listed companies in China are controlled by SOEs ${ }^{6}$. As shares held by state-owned parent entities are state shares and/or state legal person shares that had been non-tradeable until very recently, these figures remain largely up to date.

A number of factors have contributed to the predominant phenomenon of parent-listed subsidiary control predominant in the Chinese listed companies. Fundamentally, rather than to provide liquidity to investors and to function as a disciplinary mechanism for capital allocation, China's two stock exchanges have been established primarily to finance the reform of SOEs.

A quota system introduced in 1994 helped to ensure SOEs' privileged access to the domestic stock markets. Under this system, share issuance quotas were distributed to the provinces and industries. This allowed governments at various levels to give listing preference to state-owned enterprises, in spite of

5 In a recent circular that urges local governments to improve quality of listed companies, the State Council affirmed that listed companies in China are 'playing a leading role in promoting the country's enterprises reform and industrial growth.'

6 Jiang Qiangui, Vice Minister of the former State Economic and Trade Commission, 'Standardizing Behaviour and Deepening Reform, to be Creditworthy and Responsible Shareholders of Listed Companies'---Speech at the Meeting on Summarizing the Experience of Establishing Modern Enterprise System in Listed Companies, at: http://www.setc.gov cn/english/setc engl/qygg eng/qygg 0022 htm. 
the large number of high growth private firms that had sprouted with China's overall economic reform 7 . Thus, among the 1175 companies domestically listed in 2002, the number of non-state controlled firms reached only about 300. The quota system was officially abolished in 2001. However, given the increasing emphasis placed on building "large enterprises and large enterprise groups" as a national strategy to reform SOEs, the role of the Chinese stock markets in promoting large state-owned enterprises and enterprise groups does not appear to have been significantly weakened.

As Tenev, Zhang and Brefort (2002) have observed, the high occurrence of parent-subsidiary control among listed companies in China has been primarily the process of "packaging for listing" (ie, establishing subsidiaries for the special purpose of listing), a practice that has been adopted by most SOE issuers. As to the motives for "packaging for listing", first, most SOEs were of poor quality and the enterprise as a whole could hardly achieve three consecutive years' profits, an essential criteria for listing under the 1993 Company Law. ${ }^{8}$ Further, for those companies which did manage to get fully floated on the markets (indeed most companies listed before 1994 were fully listed), riddled with bad debts and non-performing assets, many of them however began running into deficits within two or three years of listing. Whilst a share delisting system was not introduced until December 20019. the poor earnings of those companies often prevented them from raising new cash through rights issues (i.e., issuing shares to existing shareholders) ${ }^{10}$. Due to the less onerous procedures compared with issuing additional shares to the public and the much lower costs than debt financing, rights issue has been the most popular further fundraising method among Chinese listed companies. Thus, combined with the quota system introduced in 1994, instead of seeking for full floatation, new issuers began to carve out a profitable line of business or 'dress up' an existing subsidiary for the specific purpose of listing. To secure control over the listed subsidiary by the state-owned parent, often only a small proportion of shares in the subsidiary were floated on the stock market. The State-owned parents would maintain at least $50 \%$ shares in the form of "state shares" or "state legal person shares" that were non-tradeable on the markets. Treating this as a practical solution to the funding problems of SOEs, partial listing was also encouraged by the central government in various documents issued by the government ${ }^{11}$.

It should be noted that in May 2005, SAAC (the State Assets Supervision and Administration Commission) and the CSRC initiated plans to float non-tradable state-owned shares ${ }^{12}$. They saw the split structure between tradable and non-tradable shares as the fundamental cause of poor corporate governance in China. While the far-reaching implications of this reform on various aspects of Chinese

7 The number of non-public owned enterprises reached 960,000 in 1997 and the non-public owned economy produced $24.8 \%$ of China's GDP. However, till Feb1999, only 8 private companies had been granted the quota for share flotation, which accounted to $1 \%$ of the companies listed in China. See Duan, Y. L. Abusing Majority Shareholder Control: Theory and Practice [Lunda Gudong Guquan Lanyong ji shili] (in Chinese), Economic Management Publishing House, Being, 2001, at 115.

8 Article 152 of the 1993 Company Law.

9 See the Revised Implementation Measures for Suspension or Termination for Listing of Loss-making Listed Companies [Kuisun Shangshi Gongsi Zanting Shangshi He Zhongzhi Shangshi Shishi Banfa (Xiuding)], issued by the CSRC in December 2001.

In 1994, the CSRC issued the Circular on Implementation of the Provisions on Regulating Share Placements in the Company Law [Zhongguo Zhengquan Jiandu Guanli Weiyuan Hui Guanyu Zhixing Gongsi Fa Guifan Shangshi Peigu de Tongzhi]. The Circular requires that companies applying for share placements should have a three year profits records and an average earning ration of $10 \%$. over those three years.

See for example, The Guiding Opinions on the Development of Internationally Competitive Large Enterprises Groups issued by the State Council in November 2001 requires the relevant government departments to support enterprises groups to list either the group as a whole or their main business on the domestic and international stock markets.

Notice of China Securities Regulatory Commission on Relevant Issues of Pilot Reform of Equity Division of Listed Companies, issued by CSRC on 29 April 2005. Note the newly initiated state share split experiments have attracted strong criticism for the feasibility and fairness of these plans in view of their ultimate compensation for public investors. So far, a few dozen pilot companies have had their schemes to float state shares approved by their public shareholders, by offering free non-tradable shares and cash compensation. These plans would allow the pilot companies to float their non-tradable shares within 2-3 years if their share prices remain at a certain level at the time of floatation. There had been two major share-merging attempts initiated by the Ministry of Finance since 1999. According to CSRC, they both failed as no prior approval was obtained from the existing minority shareholders. The new experiments give pubic shareholders more room to negotiate terms with their companies. Under s3 of the Notice on Relevant Issues of Pilot Reform of Equity Division of Listed Companies, a pilot company's share merging plan need to be approved by $2 / 3$ of the ordinary shareholders participating in the vote and $2 / 3$ of the circulating shareholders participating in the vote. 
corporate governance have yet to be revealed, it is anticipated that the market for corporate control will become more active when the market becomes liquid ${ }^{13}$.

However, given the infancy of the Chinese stock market, the concentrated ownership is unlikely to be fundamentally changed in the foreseeable future. This is consistent with the theory of 'path dependence', which postulates that a country's patterns of corporate ownership structure are likely to depend on the patterns set down at earlier times ${ }^{14}$. From a practical perspective, the non-circulated capitalisation of Chinese stock markets had exceeded RNB 3 trillion by June 2005, as compared to the RMB 1.4 trillion circulated market capitalisation. Getting such a huge amount of state assets floated onto the markets in a short period seems to be unattainable, not to mention the current sluggish markets that have been incepted by the state share reduction trials carried out about four years ago. Further, a recent circular issued by SASAC shows that even if the state shares become liquid, the State may not be prepared to withdraw from all state-owned/controlled companies, especially the most profitable ones ${ }^{15}$.

Given this dominant feature of partial listing of SOEs, abuse of majority control has been a major concern of the Chinese stock market regulator. In the Code of Corporate Governance for Listed Companies in China adopted by the CSRC in 2002, Chinese listed companies are required to separate themselves from their parent entities in terms of personnel, finance, capital, business and organisation. The rampant corporate scandals in the Chinese stock markets involving false accounting and "tunnelling" (diversion of funds from listed companies for other use) however have meant that, in spite of such regulations, the status of listed companies as independent legal entities (as commonly understood in the West) may not be taken for granted in the Chinese context. This is also the major factor that calls for a corporate group-based approach to look at issues of corporate governance in listed companies in China. That is, rather than simply focusing on the firm level of the listed companies, the extent of parent-subsidiary control in the Chinese stock markets will be examined through investigating the various instruments of control over listed companies by their state owned parents. In addition, by employing such an approach, the impact of parent-subsidiary control on other internal and external parameters that would influence the decision-making process and accountability of the listed subsidiaries' boards will also be studied. This is to be further illustrated with the conceptual framework set out later.

\section{Conceptual Framework for a Corporate Group and Shareholder Control Perspective on Corporate Governance}

As mentioned, the corporate governance structure and practices in Anglo-American countries are premised on separation of ownership and control and the reduction of agency costs, derived from the inevitable diversion of the interests of managers from those of the shareholders (Jensen and Meckling 1976). Thus, a wide range of internal mechanisms (such as mandatory disclosure of information, independent directors and executive remuneration) are designed ex ante to complement the external mechanisms (such as market for corporate control, labour market and outsider participation). The rise of institutional shareholders in the 1990s has been seen as an important 'monitoring mechanism' (Stapledon 1996).

However, where the great majority of a country's listed companies are subject to the control of closely held parent entities, the balance of this institutional mix could be altered. As researchers such as Shleifer and Vishny (1996) have pointed out, concentrated ownership by itself is not necessarily a bad thing. Where a company has a controlling shareholder, agency costs could be reduced. This is because the controlling shareholder may have strong incentives to select and monitor managers and maximise Mark J. Roe (ed), Convergence and Persistence in Corporate Governance, Cambridge University Press, 2004, 112. 
profits (Jensen and Meckling1976). It was based on these grounds that Sheilfer and Vishny (1996) suggested that the best corporate governance could be achieved by a combination of large shareholders and strong legal protection for investors.

Note however large shareholder/parent entity control has its downside. On the one hand, there are the trade-offs between the positive role of large shareholders in supervising the management and the negative "entrenchment effects" associated with large ownership (Claessens 2002). On the other hand, when a parent entity effectively controls the operations of its listed subsidiary, there is an obvious risk that the parent entity may dictate the affairs of the subsidiary to exploit its minority shareholders (Hadden 1978). According to La Porta et al.(2000), expropriation of the minority may take various forms, such as diversion of corporate profits, business opportunities and self-dealing. In fact, when the benefits of private control to the controlling shareholder exceeds the benefit of profit maximisation, profit maximisation may cease to be the paramount objective of listed subsidiaries (Shleifer and Vishny1996, Dyck and Zingales 2002).

The enhanced agency problem associated with the state as a majority shareholder has been documented by a number of commentators. State firms are generally regarded as less efficient in the Western literature. This is partly due to the multi-level principal agent relationships coupled with the passive and absentee ultimate owners (the whole people). Further, the multiple objectives of the state may allow non-profit maximising considerations to continue to be a factor when company decisions are made (Shleifer and Vishny 1996, Gratham 2005, Whincop 2005).

On the one hand, there is some argument that there are positive effects of having an SOE as a dominant shareholder. For example, a "publicly spirited" SOE may take a more long-term view in relation to the development of its listed subsidiaries (Tomasic, Andrews and Fu 2005). Thus it may improve the efficiency of the firms by controlling the decisions of the firms (Shleifer and Vishny 1996) and be less motivated to engage in short-term expropriation of minorities. However, such argument may be more convincing for SOEs operating in monopolistic areas where the market pressure tends to be less intense.

On a broader level, one should note that a country's system of corporate ownership and control is influenced by its social, economic, political, legal and cultural systems (Roe 2001; Cheffins 2002). Thus, the problem for outside investors in China could be further complicated by the fact that the state is not only the ultimate controlling shareholders of the majority of Chinese listed companies, but also serves as the stock market regulator, the corporate and securities lawmaker and to a lesser extent, the corporate disputes judicature.

\section{Literature Review}

Corporate governance around the world has evolved around two major sets of systems, ie., the AngloAmerican outsider and the German-Japanese insider-based models (Tam 1999). Whilst the former are premised on the phenomenon that most large firms do not have 'core' shareholders to exercise inside influence, the latter emphasise insiders (such as large shareholders and employees) involvement in corporate decision-making, as large block holders in these countries are common and usually in a position to do so (Cheffins 2002, at p15, Hopt et al.1998; Backer 2002).

The trend of globalisation of capital markets has stimulated scholarly speculations on the convergence of corporate governance models. Cheffins (2002) noted an "implied consensus" among academics that the trend of convergence was towards the Anglo-American capitalism that provides better protection to investors (Hansmann and Kraakman 2001).

On the other hand, when the "concentrated ownership" thesis as mentioned arose, the "convergence" arguments become less convincing. Some theorists argue that the convergence will not necessarily occur, as instead of simply being determined by market forces, a country's corporate ownership and control system is contingent on its economic, political, legal and cultural systems (Roe 2001; Cheffins 2002). Moreover, the "path dependence" theorists claimed that a country's corporate governance system is shaped by the system it had in place at earlier times (Bebchuk and Roe 2004). Whilst the overall 
message sent by these researchers seem to be that countries have to deal with their own problems in corporate governance under given national contexts, it has been suggested that more comparative studies at country level are needed for a better understanding of the impact of globalisation on corporate governance.

It is against this background and also with the rise of China in the global economy that corporate governance of listed companies in China has received unprecedented attention. Various achievements and problems in this respect have been scrutinised by researchers from the World Bank ${ }^{16}$, the OECD ${ }^{17}$, Standard and Poor's ${ }^{18}$, and the Institute of International Finance ${ }^{19}$. Individual researchers such as Tam (1999), Wei (2003), Schipani and Liu (2002) have also offered their views on the current status of corporate governance arrangements in China and sought to propose methods for reform.

It is useful to refer to a 2003 study conducted by the Shanghai Stock Exchange which listed eight crucial problems in the governance of Chinese companies:

“(1) Improper shareholding structure;

(2) The role of government as both regulator and owner;

(3) Inadequate legal protection for investors;

(4) The dominance of insider control and the 'key man' model in corporate management;

(5) Immaturities in external governance structure, such as the market for corporate control, the insignificant role of creditors and institutional investors;

(6) The poor quality of information disclosure;

(7) Lack of due diligence of the directors and management in performing their fiduciary duties and the supporting institutional arrangements and social norms (The Shanghai Stock Exchange stated: "the current China has still not all around formed a social and culture environment that cherishes uprightness, honesty and keeping one's words", p36); and

(8) Lack of monitoring from the media and the public" 20.

The dominance of the state as a controlling shareholder is also one of the key tensions highlighted by Tomasic, Andrews and $\mathrm{Fu}$ (2005). These three have conducted a large ARC-funded project to investigating corporate governance and accountability in China's top 100 listed companies. Some key tensions affecting corporate governance in China have been highlighted by their initial research findings.

The existing literature has provided us with considerable insights on the various problems in corporate governance in China, including the impact of large shareholder control on the poor functioning of the corporate organs of the listed companies, such as false accounting, poor information disclosure and diversion of funds from listed companies through widespread related party transactions. However, far less is known about how the control over listed companies is carried out by their parent companies as controlling shareholders. Institutions of Modern Markets, The World Bank, 2002.

The OECD has been engaged in a policy dialogue on corporate governance with Chinese government. For more information on the dialogue see OECD website, http://www.oecd.org/document/61/02340,en $264934813 \quad 34970813 \quad 1 \quad 1 \quad 1 \quad 1,00 . h \mathrm{html}$.

18 Katrina Tai and Calvin R Wong, "Standard and Poor's 2003 Country Governance Study: Corporate Governance in China”, available at: http://icf.some.yale edu/research/china/newpaper/cn/feature/mainland/coproate. 
Most existing research on corporate groups in China has focused on economic analysis. Commentators praise these giant groups for their ability to harness resources to achieve an economy of scale, but no consensus has been reached with regard to their true competitiveness and profitability.

A couple of other empirical studies have more fully explored parent-subsidiary relationships, but mainly from an economic or organisational, rather than legal perspective. For example, based on quantitative and qualitative data collected on 40 largest Chinese business groups in 1988 and 1990, Keister (2000) provided a detailed account of the process by which Chinese business groups emerged and intra-group structures. Her research found a positive correlation between the formation of business groups, interlinking directorship and the financial performance of group member firms. Whilst the first significant study on Chinese business groups in many aspects, her book did not deal with the degree of independence of these business groups from the government. Nor did the data collected in such early times allow her to consider control over listed companies by their group parents.

Inter-firm relationships in Chinese business groups have also been the focus of a more recent study by Mayer and $\mathrm{Lu}$ (2004). Based on intensive fieldwork, these two authors documented the group structure and inter-firm relationships in CIMC (China International Marine Container Company), a Shen Zhenbased world-leading manufacturer of marine shipping containers. However, the CIMC is rather an unusual state-owned corporate group. Firstly, the CIMC group, not one of its subsidiaries, is the listed entity, and secondly, rather than having one single parent entity, CIMC is a joint venture of two other state-owned enterprises, each holding $20 \%$ of non-circulating shares in the group. This partly explains the considerable distance between CIMC and its parent entities. The authors did point to the fact that parent-subsidiary relationships in groups with one single parent entity may be significantly different, and in those groups the feature that 'Chinese business firms as hierarchically nested systems ... rather than discrete units' may be more evident. Therefore, according to these two authors, more empirical research on how business groups in China manage their 'indefinite boundaries' is needed.

Within the Anglo-American jurisdictions, in view of the few legal studies on corporate groups, British scholar Hadden remarked:

"There is surprising little precise information on the way in which large corporate groups structure their operations. Large corporate groups are all too often regarded as monolithic 'black boxes' in which senior executives conspire secretly to pursue their economic and political objectives." (Hadden 1984, p271)

Since then, group relationships have been the research focus of several corporate law scholars including Lumberg (1993) and Ramsay and Stapledon (1998). In their empirical study of corporate governance of the top 500 listed companies in Australia, Tomasic and Bottomley (1993) observed the tendency of integration of management and finance within large corporate groups in Australia. However, given the still relatively small number of empirical studies, Hadden's comment remains largely valid.

As such, before delving into the issues on which further research needs to be carried out, it is useful to sum up that a corporate group and shareholder control perspective will make a substantial contribution to the existing literature on corporate governance in the following areas:

- As opposed to individual firms, the study of parent-subsidiary control provides an alternative approach to the governance of listed companies in China;

- Although the 'control' that exists inside corporate groups has recently received much attention, there is inadequate empirical research on how effective control of subsidiaries is carried out over subsidiaries by parent entities. As such, an analysis of parent-subsidiary control in the Chinese listed companies will assist our understanding of the phenomenon of concentrated share ownership in other parts of the world.

- A corporate group contextual-based regulatory framework will contribute to the ongoing international debate on the relative effectiveness of rival systems of corporate governance. 


\title{
Concluding Remarks: Future Research Agenda
}

A corporate group and shareholder control perspective on corporate governance in China would require research in two major aspects, namely, a discovery aspect and a reform recommendation aspect.

\section{The Discovery Aspect}

This aspect could be informed by an investigation of the various mechanisms of control over listed subsidiaries employed by their state-owned parent companies. The intricate network of control mechanisms within corporate groups has been summarised by Hadden in the following way:

\begin{abstract}
“...there is a tendency for central management at group headquarters to assert much greater control over the day-to-day activities of its subsidiaries. In such cases, the finance of the group as whole is likely to be centralised with banking and corporate finance functions being performed by the entire group through the parent company's treasury operations. Management in operating subsidiaries is typically required to obtain the approval of group headquarters for all major investments and to report at specified intervals on their trading performance and prospects. They may also be required to price their products for intragroup trading, known as transfer pricing, in such a way as to produce a profit in whichever subsidiary or jurisdiction is most advantageous to the group as a whole." 21
\end{abstract}

Adopting a comparative perspective, further research would need to look into the following issues in corporate groups involving listed companies in China:

\section{Patterns of group structures and size of corporate groups}

Due to the listing priority previously given to the large state-owned enterprises and enterprise groups, rather than simply affiliated to one closely held parent entity, many Chinese listed companies reside within a nested group structure comprising a number of listed and unlisted companies. The listed subsidiary, as a fundraising vehicle of the parent entity, may be charged with functions different from other group companies and therefore subject to different levels of parent-subsidiary control. However, as pressure on the listed subsidiary from the parent company may take place indirectly, e.g., through transactions forced on the listed company through another group subsidiary, it will be useful to get an idea of the typical patterns of group structures and the sizes of corporate groups involving listed companies in China. To carry out such an investigation, the recent annual reports of listed companies in China could be a ready source to start with.

\section{Parent-subsidiary control through personnel integration}

As the composition of the board of directors provides the critical link between ownership and corporate governance, interlocking directorship is often seen as an important control mechanism within corporate groups. Therefore in terms of personnel integration, it will be useful to study to what extent the parent entity plays a role in deciding the composition of the board of its listed subsidiary.

Furthermore, as PRC companies are in a stage of transition from the old system of governance consisting of the Communist Party Committee, the Management Committee and the Trade Union (the so-called old three) to the new governance systems, ie., the shareholders general meeting, the board of directors and the board of supervisors (the so-called new three), the lingering influence of the old system and old ideas of corporate governance could mean that the board of directors is far from being the major factor (or the sole factor) that bands the parent entity and the listed subsidiary.

For example, in spite of the existence of the two-tier boards, recent studies have shown that the Chairman is often a powerful figure dominating the boards of directors in large state-controlled listed companies. This is sometimes seen as some repercussion of the old system in the former SOEs where a 
factory director (manager) assumed the overall responsibility for management of the enterprise and also acted as the legal representative of the enterprise. As such, it would be useful to study to what extent the Chairman plays a role in strengthening the ties between the parent entity and the listed subsidiary.

Another factor which may further complicate the issue of personnel integration within Chinese corporate groups is the role of the Communist Party. The Party Committee used to be the top governance structure in former SOEs and the local Party organisation also played a decisive role in both appointing factory directors and supervising their performance. As the Party is likely to remain a permanent fixture in PRC listed companies in the long term ${ }^{22}$, more study is needed to find out the interaction between the Party Committee and the newly established board of directors in the listed companies.

\section{Parent-subsidiary control through involvement in business decision-making}

In a publicly traded company, shareholder rights are generally exercised through voting on important corporate matters, such as mergers and liquidations, as well as in elections of boards of directors. The powers of the shareholder general meeting and the board of directors are stipulated in the 1993 Company Law. However, as there are always gaps between the law in books and the commercial reality of corporate groups, it will be useful to study how the law governing the powers of the shareholders general meeting, the Chairman and the board of directors operate in practice. From another perspective, this is to investigate the independence and accountability of the board of listed subsidiaries in fulfilling its duties to company shareholders as a whole, rather than simply the controlling shareholder.

\section{Parent-subsidiary control through financial integration}

Information on the degree to which the finances of a corporate group is integrated and centrally managed is particularly important to analyse the extent of parent-subsidiary control. In addition, in the context of the Chinese listed companies, manipulation of financial information of listed companies and the problem of related party transactions have been widely criticised by both investors and academics. For a better understanding of the financial aspect of corporate groups, it will be useful to find out to what extent these problems exist and how these activities are carried out within Chinese corporate groups.

Apart from reviewing the recent company annual reports, structured interviews with a number of company insiders (company officers) and outsiders (lawyers/independent directors/institutional investors) are necessary to carry out a study on the issues as mentioned above. Getting access to companies could be an issue but would not be particularly difficult, taking into account (i) the fact that these companies are listed companies makes them more open due to market expectations of transparency; (2) from the author's own experience, the Chinese companies are increasingly geared up to dealing with outsiders seeking information about them, as they are seeking investors; and (3) the interviews would only be used for gaining perspectives on how corporate groups operate in China, rather than soliciting information of individual companies.

\section{Regulatory Reform Proposal}

Based on findings on the discovery aspect, the reform proposal aspect should aim at identifying ways in which the parent-subsidiary relationships could be better regulated to reduce further damage to the interests of minority shareholders in Chinese listed companies. This would require the assessment of the current regulatory framework for the governance of listed companies in China. The way that corporate groups are dealt with under the Anglo-American system and the German Japanese system could also be relevant.

In dealing with the parent-minority shareholder conflicts, countries have been divided along the lines of the entity approach and the enterprise approach (Dine 2000). Under the German enterprise approach,

22 Article 19 of the 2005 amendment of the PRC Company Law provides that the organisation of the Communist Party of China shall be established in a companies so as to carry out their activities and the company shall provide the Party organisation with conditions necessary to carry out its activities. 
parent companies may treat their subsidiaries as within the same enterprise through a formal control agreement with subsidiaries, guaranteeing the position of minorities and creditors (Hadden 1978). In Australia, there is continued adherence to the separate entity approach, but legislation has been introduced to operate alongside the common law 'veil piercing doctrine' to protect interests of minority shareholders in group companies (Gillooly 1993). Furthermore, in May 2000, the Australian Companies and Securities Advisory Commission published Corporate Groups final report. Seeking to stimulate discussion on how corporate groups should be viewed and treated, the Report outlines various areas of law relating to corporate groups. This report, which extended the study by Ramsay and Stapledon (1998), provides a good point of reference for designing the framework for regulating parent-subsidiary relationships in China.

Note however, no matter how comprehensive a system is in place, agency costs could only be reduced but not eliminated. On the other hand, given the multitude of determinants of corporate governance, not all problems of corporate governance could be solved by the introduction of a mandatory model of corporate law. This is particularly the case when the state acts not only as the parent entity, but also the regulator, the adjudicator the and corporate and securities lawmaker. Thus, a social-legal approach will also need to be employed to examine the factors that would affect the effectiveness of any regulatory reform in the Chinese context.

\section{References}

Berle A and Means G (1932), The Modern Corporation and Private Property, MacMillan, New York. Roe, M. (2001) “ The End of History for Corporate Law”, 89 GEO L.J. 439(2001).

Rafael La Porta et al.(1997), "Legal Determinants of External Finance", 52 J. FIN 1131, 1137-38.

Clark D. C.(2003), "Corporate Governance in China: An overview", in China Economic Review, 2003, vol. 14 , issue $4,494-507$, paper available at:

http://www.law.gwu.edu/facweb/dclarke/pubs/corpgov-final.pdf

Claessens, S , Diankov, S., and Lang, L. (2000), "The Separation of Ownership and Control in East Asian Corporations", 58 Jul of Financial Economics 81-112

Claessens, S., Diankov, S., Fan, J. H. and Lang, L. (2002) "Disentangling the incentive and Entrenchment effects of large shareholdings", 57 The Journal of Finance 57, 2741 -2771.

Companies and Securities Advisory Committee, Corporate Groups Final Report, AGPS.

Dyck, A. and Zingales, L. (2002), Private Benefits of Control: An International Comparison, paper available at http://nber.org/papers/w8711.

Gillooly, M. (1993), The Law Relating to Corporate Groups, Federation Press.

Gratham, R. (2005) "The governance of government owned corporations", 23 C\&SLJ 181

Gorton, G and Schmid, F (1996), 'Universal Banking and the Performance of German Firms,' National Bureau of Economic Research Working Paper No. 5453, Cambridge, MA.

Henry Hansmann and Reinier Kraakman (2001), "The End of History of Corporate Law", 89 GEO L J $439,452$.

Hadden, T (1978), Company Law and Capitalism, Second Edition, Weidenfeld and Nicolson, London.

Hadden, T (1984), Inside Corporate Groups, International Journal of the Sociology of Law 1984, 12 271-286.

Hutchinson, T (2002), Research and Writing in Law, Lawbook Co.

ICC (2004), "China Task Force Report on Corporate Governance", ICC corporate Governance Website, http://www.iccwbo.org/CorpGov/stories/June 14 2004-CTF\%20Report.asp

Jensen M and Meckling (1976), "Theory of the Firm: Management Behaviour, Agency Costs, and Capital structure" 3 Jnl of Financial Economics 305-60.

Johnson, S., La Porta, R., Lopez-de-Silanes, and Shleifer (2002), "Tunnelling”, in Markets and Company Law, Hopt, K. J. and Wymeersch, E. (eds), Oxford University Press.

Kaplan, S. N. (1997) 'Corporate Governance and Corporate Performance: A Comparison of Germany, Japan and the US', in Hopt K J and Wymeerch (eds), Comparative Corporate Governance, Essays and Materials, Walter de Gruyter, Berlin, 1997, pp195-210. 
Duan, Y. L., Abusing Majority Shareholder Control: Theory and Practice [Lun Dagu Dong Guquan Lanyong Ji Shijian] (in Chinese), Economic Management Press.

Keister, L.A. (2000), Chinese Business Groups: The Structure and Impact of Interfirm Relations during Economic Development, Oxford University Press.

La Porta et al. (1999), "Corporate Ownership around the World", Journal of Finance, 54, PP. 471571.

Meyer, M. W. and Lu, X. (2004), "Managing Indefinite Boundaries: The Strategy and Structure of a Chinese Business Firm", in Management and Organization Review, 1:1 57-86.

Paredes T.A. (2004), "A systems Approach to Corporate Governance Reform: Why Importing U.S. Corporate Law Isn't The Answer”, http://ssrn.com/abstract=519264

Ramsay, I. M. and Stapleton, G. P. (1998), Corporate Groups in Australia (Research Report, Centre for Corporate Law and Securities Regulation, University of Melbourne.

Shanghai Stock Exchange (2003), "China Corporate Governance Report 2003: Executive Summary", 2003, at: http://rru.worldbank.org/Discussions/OpenFile.aspx?id=1284.

Schipani, C. A. and Liu (2002), 'Corporate Governance in China: then and now,' Columbia Business Law Review, vol. 2002 No. 1 pp 1-69.

Shleifer, A. and Vishny, R. W. (1996), A Survey of Corporate Governance, NBER Working Paper Series, National Bureau of Economic Research, Cambridge.

$\mathrm{Su}, \mathrm{W}$. K., Ownership Structure and Corporate Performance in Chinese Listed Companies [Zhongguo Shangshi Gongsi Guquan Jiegou Yu Gongsi Jixiao] (in Chinese), Economic Science Press, 2003

Tai, K. and Wong, C. R. (2003), "Standard and Poor's 2003 Country Governance Study: Corporate Governance in China", available at: http://icf.some.yale.edu/research/china/newpaper/cn/feature/mainland/corporate

Tam, O. K (1999), The Development of Corporate Governance in China, Cheltenham: Edward Elgar.

Tenev, S., Zhang, C. L. with Brefort L (2002), Corporate Governance and Enterprise Reform in China: Building the Institutions of Modern Markets, The World Bank.

Tomasic, R and Bottomley, S. (1993), Directing the Top 500: Corporate Governance and Accountability in Australian Companies, Allen \& Unwin, St leonards, NSW.

Whincop, M.J. (2005), Corporate Governance in Government Corporations, Aldershot, Ashgate Publishing.

Williams, C. (1991) "Case Studies and the sociology of gender" in Feagin JR, Orum A and Sjoberg G (eds), A Case for the case Study, Chapel Hill and London: The University of North Carolina Press, 1991: 226

Wei, Y. W. (2003), Comparative Corporate Governance, A Chinese Perspective, Kluwer Law International.

Whincop, M. J. (2005), Corporate Governance in Government Corporations, Aldershot, Ashgate Publishing.

\section{Acknowledgement}

This is a revised version of a paper originally presented to the Business Research Conference, Victoria University Melbourne November 2005. The author would like to thank Professor Roman Tomasic, Faculty of Business and Law of Victoria University for his useful comments on an earlier version of the work. 